\title{
Analysis of clinical and genetic features among 12 neonatal diabetes mellitus
}

\author{
Cao Bingyan*, Gong Chunxiu, Yang Jinkui, Cao Xi, Wu Di \\ From 7th APPES Biennial Scientific Meeting \\ Nusa Dua, Bali. 14-17 November 2012
}

\section{Objectives}

To analyze the clinical and genetic features among 12 neonatal diabetes mellitus (NDM).

\section{Methods}

Describe clinical features of 12 diagnosed NDM cases in my hospital between Jul. 2001 and Jun. 2012. KCNJ11, ABCC8 and INS gene were sequenced in all patients.

\section{Results}

The age at diagnosis was between 0.5 and 5 month, the median was 3 month. 7 cases (58.3\%) were SGA. Infection occurred in 7 cases, 4 cases with convulsion and 8 cases with ketoacidosis. The mean HbA1c at diagnosis was $10.0 \%(7.4 \% \sim 13.7 \%)$. Insulin treatment was started in all 12 patients, the initial dose was $1.0 \sim 1.2 \mathrm{IU} / \mathrm{kg} / \mathrm{d}, 6$ cases were treated with glyburide after the acute phase, only one boy who diagnosed as DEND syndrome reached euglycemia. 2 cases stopped glyburide because of gastrointestinal adverse reaction. Among the 12 cases followed up, 7 had PNDM, 4 had TNDM, 1 case lost following, 2 cases died, one was the DEND syndrome patient died of DKA, the other died of hepatic and renal failure at the age of 1 year and 6 months. One had skeletal dysplasia and diagnosed as Wolcott-Rallison syndrome. The blood glucose of most patients was well controlled. KCNJ11c.175G>A (V59M) and $\mathrm{KCNJ} 11 \mathrm{c} .601 \mathrm{C}>\mathrm{A}(\mathrm{R} 201 \mathrm{H})$ mutation were found in two patients.

\section{Conclusion}

The clinical expressions of NDM were atypical and easily missed diagnosis. Of all the NDM cases, 30\% was TNDM and relieved automatically. Insulin was the best choice

Beijing Children's Hospital, Capital Medical University, Beijing, China before genetic identification. The KCNJ11 mutation rate of PNDM was $28 \%$ in China.

Published: 3 October 2013

doi:10.1186/1687-9856-2013-S1-P5

Cite this article as: Bingyan et al: Analysis of clinical and genetic features among 12 neonatal diabetes mellitus. International Journal of Pediatric Endocrinology 2013 2013(Suppl 1):P5.
Submit your next manuscript to BioMed Central and take full advantage of:

- Convenient online submission

- Thorough peer review

- No space constraints or color figure charges

- Immediate publication on acceptance

- Inclusion in PubMed, CAS, Scopus and Google Scholar

- Research which is freely available for redistribution
( Biomed Central

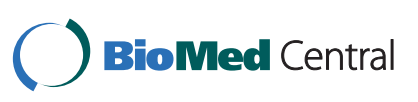

(c) 2013 Bingyan et al; licensee BioMed Central Ltd. This is an Open Access article distributed under the terms of the Creative Commons Attribution License (http://creativecommons.org/licenses/by/2.0), which permits unrestricted use, distribution, and reproduction in any medium, provided the original work is properly cited. 